(C) В.П. Андрущенко, А.П. Кудін, О.С. Падалка, І.В. Вакуленко, Г.В. Жабєєв, 2011 ISSN 2076-8184. Інформаційні технології і засоби навчання. 2011. №1 (21). Режим доступу до журналу: http://www.journal.iitta.gov.ua

УДК 378.4:004

Андрущенко Віктор Петрович, доктор філософських наук, професор, академік НАПН України, член-кореспондент НАН України, ректор Національного педагогічного університету імені М. П. Драгоманова, м. Київ

Кудін Анатолій Петрович, доктор фізико-математичних наук, професор, проректор 3 дистанційної освіти та інноваційних технологій навчання, Національний педагогічний університет імені М. П. Драгоманова, м. Київ

Падалка Олег Семенович, доктор педагогічних наук, професор, член-кореспондент НАПН України, проректор з організації навчально-виховної роботи і економіки, Національний педагогічний університет імені М. П. Драгоманова, м. Київ

Вакуленко Ірина Вікторівна, викладач кафедри інформаційно-комунікаційних технологій та електронних засобів навчання Інституту дистанційного навчання, Національний педагогічний університет імені М. П. Драгоманова, м. Київ

Жабєсв Георгій Володимирович, кандидат педагогічних наук, доцент кафедри інформаційно-комунікаційних технологій та електронних засобів навчання Інституту дистанційного навчання, Національний педагогічний університет імені М. П. Драгоманова, м. Київ

\title{
ЗАГАЛЬНОУНІВЕРСИТЕТСЬКИЙ ПРОЕКТ «ЕЛЕКТРОННА ПЕДАГОГІКА»: ТРЕТІЙ ЕТАП
}

\section{Анотація}

3 метою створення сучасного інформаційно-освітнього середовища НПУ імені М. П. Драгоманова була розроблена концепція загально-університетського проекту «Електронна педагогіка». Детально описані етапи і задачі проекту. Наведено плани майбутніх етапів проекту.

Ключові слова: проект, електронні засоби навчання, інформаційнокомунікаційні технології, Інтернет, мережа, мультимедія, дистанційне навчання.

Постановка проблеми. Педагогіка постіндустріального (інформаційного) суспільства вимагає не тільки швидкого адаптування до сучасних інформаційнокомунікаційних реалій, а й створення умов, які сприяють розвитку у людини здібностей самостійно розв'язувати освітні проблеми у динамічному режимі. Це 
актуалізує створення інформаційно-освітніх середовищ вищих навчальних закладів в Інтернеті (IIOC). Процес навчання в такому середовищі безпосередньо спирається як на традиційне дидактичне і технічне забезпечення, так і на спеціальні форми організації навчального процесу, у якому традиційні форми навчання набувають нових якостей і змісту. Тому в останні роки набуває поширення новий напрямок педагогічної науки, який досліджує педагогічні процеси в IIOC. Він дістав назву «Електронна педагогіка» [1]. У рамках електронної педагогіки IIOC — це віртуальне середовище, створене програмно-педагогічним комплексом сервісних послуг (програмних модулів) й інформаційних ресурсів, які забезпечують навчальний процес у певному навчальному закладі. Водночас склад і зміст інформаційних ресурсів визначається самим навчальним закладом, а набір сервісних служб - типовим програмним забезпеченням. Адміністрування IIOC веде навчальний заклад, реалізовуючи свою методику навчання на основі типових навчальних стандартів.

Стратегічним напрямом розвитку Національного педагогічного університету імені М. П. Драгоманова на шляху становлення його як сучасного європейського дослідницького університету $є$ впровадження у навчальний процес інноваційних проектів. Одним із таких став широкомасштабний загально-університетський проект «Електронна педагогіка», метою якого $є$ створення сучасного інформаційноосвітнього середовища НПУ імені М. П. Драгоманова на основі новітніх інформаційно-комунікаційних технологій [2-4]. У даній роботі представлені концептуальні засади створення IIOC і представлені результати перших етапів проекту.

Головні завдання проекту:

1. Високоякісна сучасна підготовка майбутніх учителів незалежно від спеціальності 3 питань ефективного використання сучасних інформаційнокомунікаційних технологій у реальному навчальному процесі.

2. Активне впровадження в усі сфери діяльності університету інформаційнокомунікаційних технологій з метою перетворення НПУ імені М. П. Драгоманова в «Електронний університет».

Наукові консультанти: компанія Cisco Systems (США); університет Umea (Швеція); університети-члени Асоціації університетів східної і західної Європи (AEEN). У проекті беруть участь усі інститути і кафедри університету, відокремлені 
навчальні підрозділи (36), спеціальні підрозділи університету - Інститут дистанційного навчання і Центр впровадження електронних систем навчання НПУ імені М. П. Драгоманова. Проект розпочато у 2005 році. Умовно він розбитий на три етапи. Перший - це підготовчий етаn: 2005-2007 роки.

1. Створення інфраструктури інформаційно-освітнього середовища університету.

2. Підготовка спеціалістів з інформаційно-комунікаційних технологій.

3. Розробка нормативно-технічної і нормативно-правової документації.

1. Створення інфраструктури інформаційно-освітнього середовища НПУ імені М. П. Драгоманова.

Розгляд сукупності цілей функціонування освітнього середовища дав можливість сформувати в освітньому середовищі такі інформаційні контури управління (рис. 1).

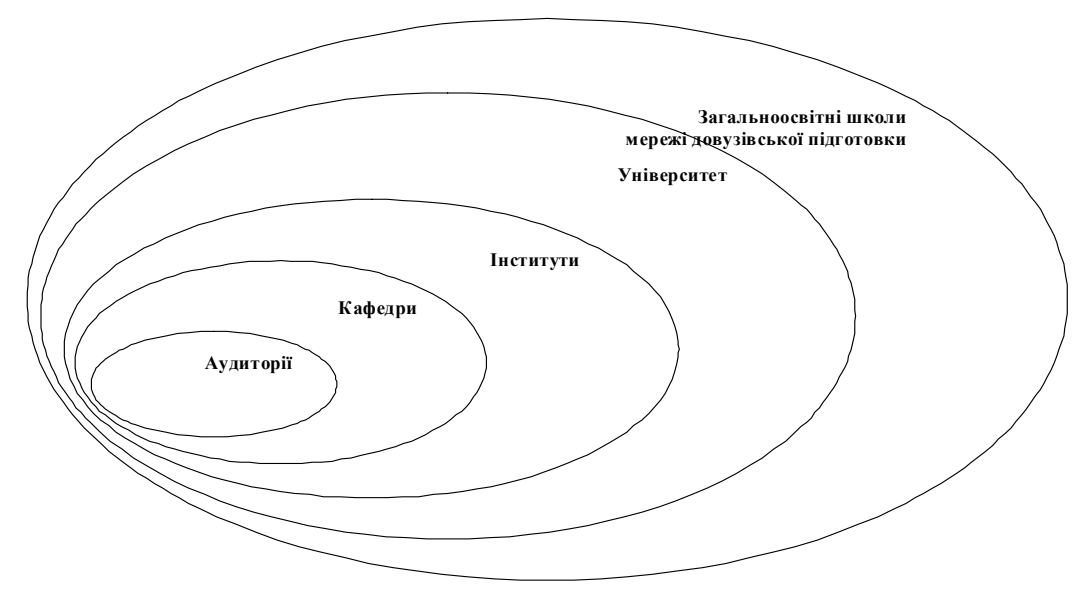

Рис. 1. Інфраструктура інформаційно-освітнього середовища НПУ імені М. П. Драгоманова

1. Контур взаємодї зовнішнього освітнього середовищуа з інформащійними ресурсами університету. Цей контур охоплює університет і загальноосвітні школи створеної мережі довузівської підготовки (система загальноосвітніх шкіл, які мають відповідні угоди 3 університетом із питань забезпечення профорієнтаційної діяльності). Функціональне призначення контуру: взаємодія зовнішнього освітнього середовища (МОН, загальноосвітні школи мережі НПУ) з інформаційними ресурсами університету; організація навчального процесу перепідготовки і підвищення 
кваліфікації вчителів загальноосвітніх шкіл системи довузівської підготовки з питань використання інтерактивних інструментів і технологій навчання.

2. Центральний навчально-методичний контур університету. Цей контур охоплює Центр впровадження систем електронного навчання (ЦК університету на вул. Пирогова, 9), загально-університетські центри електронного навчання (у кожному навчальному корпусі), кафедри i навчальні аудиторії інститутів університету. Призначення: Організації i навчально-методичне забезпечення навчального процесу з питань підвищення кваліфікації і перепідготовки вчителів загальноосвітніх дисциплін.

За 2003-2005 рік введено в дію й оснащено за останніми досягненнями електронної техніки загально-університетський Центр впровадження засобів електронного навчання НПУ імені М. П. Драгоманова (рис. 2). За своєю структурою Центр складається 3 двох зон: зони технічних служб (Служба порталу, робочі місця адміністраторів і Веб-дизайнерів) і зони апробації електронних навчальних систем i інструментів. Центру відводиться головна роль у системі курсової підготовки навчально-допоміжного складу університету, місце зберігання виготовлених цифрових освітніх ресурсів. Тут знаходяться системи життєзабезпечення локальної мережі університету. Через Центр здійснено забезпечення кожної кафедри університету (102) програмним і технічним обладнанням (ПК, сканери, мережа, Інтернет).

\section{Схема „Центру впровадження засобів електронного навчання"}

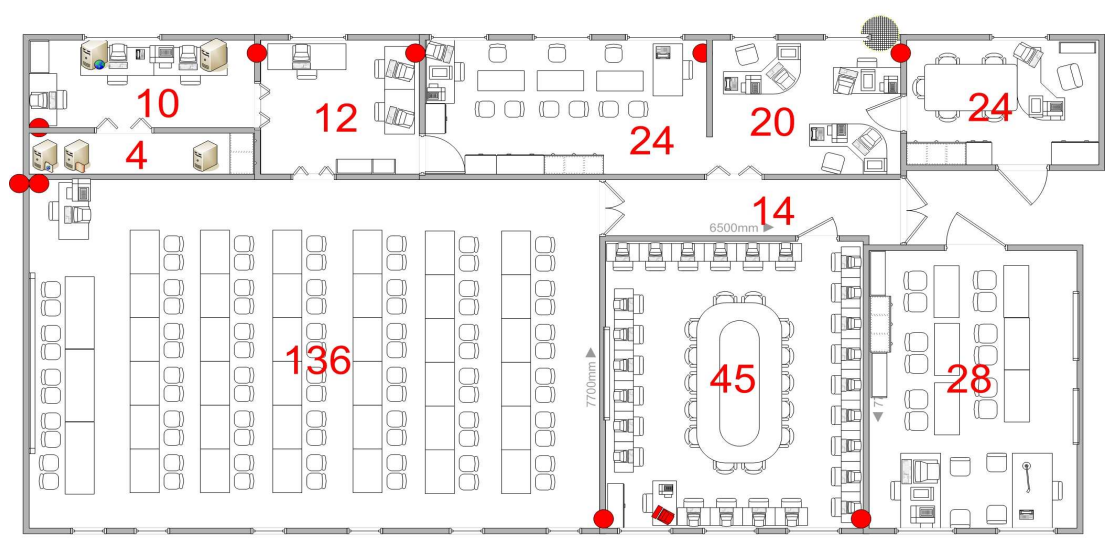

Центральний корпус, 3 поверх, праве крило

Рис. 2. Центр впровадження засобів електронного навчання 
На базі Центру розгорнуто роботу декількох науково-виробничих лабораторій. У лабораторії засобів електронного навчання розробляються технології виготовлення цифрових освітніх ресурсів. Лабораторія електронного навчання працює над створенням технологій електронного навчання (комп’ютерне тестування, програмні продукти для підтримки дистанційного навчання). Лабораторія запису відеолекцій відповідає за розробку банку мультимедійного наповнення навчального процесу. Служба порталу адмініструє мережу Інтранет і контролює роботу освітнього порталу університету. Центр комп'ютеризації відповідає за встановлення й обслуговування комп'ютерної техніки і мережевого обладнання в усіх підрозділах університету.

Однак, окрім створення і апробації навчальних засобів, важливим у педагогіці $\epsilon$ демонстрація їx. 3 метою ефективного пропагування нових електронних засобів i технологій навчання і проведення реального навчального процесу з використанням їх було розроблено модель мультимедійного центру загально-університетського призначення на основі досягнень НiТech-технологій. Такий центр уведено в дію у головному корпусі університету (рис. 3).

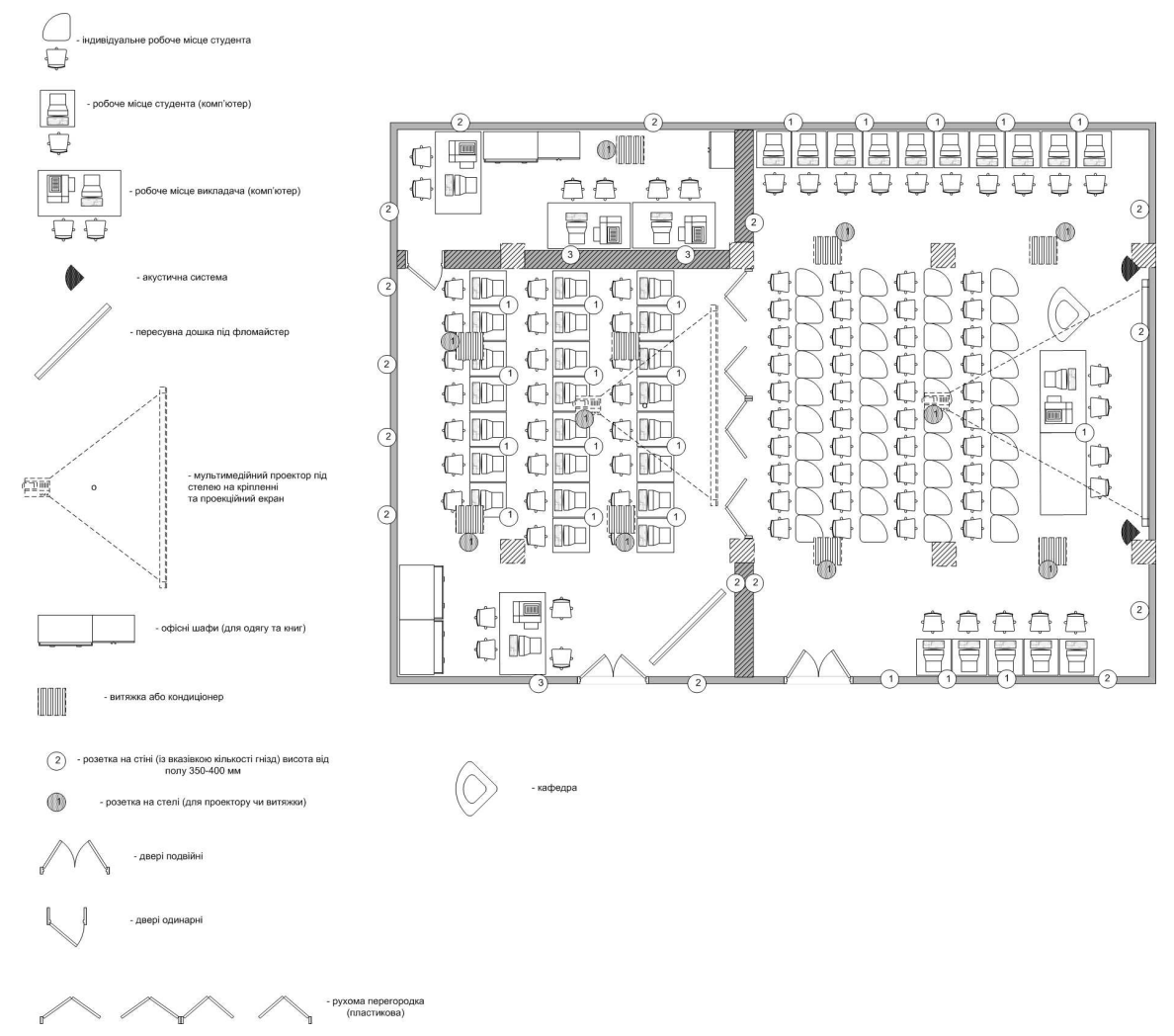

Рис. 3. Мультимедійний центр електронного навчання

Це багатофункціональне приміщення, яке складається з трьох блоків: перший блок - це мультимедійна аудиторія для лекційних занять; другий - це мережевий 
комп'ютерний клас на 25 ПК, який може використовуватись і як мовна цифрова лабораторія; третій блок - лабораторія створення і зберігання мультимедійних засобів навчання. Два перших блоки розділені рухомою стіною (ролети), що дозволяє, як збільшувати число слухачів лекцій до 80, так і проводити окремо практичні заняття в двох аудиторіях з використанням мультимедія одночасно (є окремі виходи). А також проводити міжсесійні форми комп'ютерного контролю для великого числа студентів (до 60 осіб одночасно). Основні задачі: створення систем доступу учасників навчального процесу до ресурсів; організація навчального процесу на основі інтерактивних інструментів і технологій навчання; проведення оперативного відео контролю, зборів, нарад, відкритих занять в реальному режимі часу; міжсесійні форми контролю.

Такі мультимедійні центри озброєні найсучаснішими електронними засобами ведення навчального процесу (дисплейні класи, мультимедійні проектори, інтерактивні дошки, пульти для оперативного опитування) й інженерними рішеннями (рухомі перегородки, потужні кондиціонери і вентиляційні системи, різні типи освітлення, навчальні меблі у стилі Hi-Tech). Такі центри будуть створені спочатку по одному у кожному навчальному корпусі і слугуватимуть місцем, де викладач будьякої кафедри університету зможе підготувати і провести навчальне заняття 3 використанням широкого спектру електронних засобів i найсучасніших інформаційно-комунікаційних технологій. Надалі, у разі зростання завантаженості використання цього приміщення викладачами і студентами під час навчального процесу, планується створення декількох таких центрів у корпусах, а, можливо, і в кожному інституті. Усе буде залежати від темпів інформатизації навчального процесу в інститутах.

3. Контур освітнього середовищуа кафедр університету. Контур освітнього середовища кафедри охоплює управління кафедрою i кафедральні навчальні тренажерні аудиторії, цифрові мовні лабораторії, дисплейні класи. Функціональне призначення: ознайомлення в ході навчального процесу студентів НПУ імені М.П.Драгоманова - майбутніх учителів - 3 інтерактивними інструментами i технологіями навчання. Основні задачі: участь в розробці цифрових освітніх ресурсів для інтерактивного навчання; апробація інтерактивних інструментів і технологій навчання; проведення лекцій і практичних занять у студентів 3 використанням 
інтерактивних інструментів i технологій навчання; проведення тестування i накопичення статистики результатів випробувань.

4. Контури навчальних аудиторій $i$ лабораторій. Інформаційні контури навчальних аудиторій $\mathrm{i}$ лабораторій $\epsilon$ контурами найнижчого рівня IIOC університету. Якщо перші, з технічної точки зору, нічого оригінального не являють, то на лабораторії покладена важлива науково-дослідницька роль: це майданчик для проведення експерименту, наукового пошуку і перших апробацій.

\section{2. Підготовка спеціалістів 3 інформаційно-комунікаційних технологій.}

Саме на них, на наступному етапі проекту, була покладена задача організації i проведення курсової підготовки навчально-допоміжного складу кафедр і викладачів, які вперше освоювали ІКТ у своїх практичній діяльності. Треба розуміти, що в університеті 95\% кафедр - гуманітарні кафедри. Така підготовка здійснювалась шляхом стажування, як за кордоном (США, Швеції, Китаю), так і проходженням курсової підготовки в навчальних центрах відомих розробників програмного забезпечення м. Києва, м. Одеси і м. Хмельницького. Так наші спеціалісти пройшли сертифікаційне стажування у комп'ютерних центрах Layola College (США), університету Umea (Швеція), отримали сертифікати за програмою MSDN Academic Alliance (Microsoft) тa Apple (США).

3. Розробка нормативно-правової бази проекту. Через відсутність створеної в українському правовому полі комплекту нормативно-правової бази, яка регламентує впровадження інноваційних технологій у практику, в університеті була створена своя, яка пройшла затвердження у встановленому порядку (табл. 1).

Таблиия 1. Нормативно-правова база

\begin{tabular}{|l|l|}
\hline Документ & Зміст \\
\hline $\begin{array}{l}\text { «Концепція розвитку дистанційної освіти в } \\
\text { НПУ імені М. П. Драгоманова» }\end{array}$ & $\begin{array}{l}\text { Основні напрямки впровадження } \\
\text { дистанційних технологій у діяльність } \\
\text { університету }\end{array}$ \\
\hline $\begin{array}{l}\text { «Положення про дистанційне навчання у НПУ } \\
\text { імені М. П. Драгоманова» }\end{array}$ & $\begin{array}{l}\text { Принципи організації дистанційного навчання } \\
\text { в університеті }\end{array}$ \\
\hline $\begin{array}{l}\text { «Положення про визнання інформаційних } \\
\text { ресурсів системи дистанційного навчання та їх } \\
\text { окремих елементів як навчально-методичних } \\
\text { праць» }\end{array}$ & $\begin{array}{l}\text { Означення інформаційних ресурсів системи } \\
\text { ДН, механізм проходження експертизи, } \\
\text { порядок прирівнювання до навчально- } \\
\text { методичних праць }\end{array}$ \\
\hline $\begin{array}{l}\text { «Положення про локальний центр } \\
\text { дистанційного навчання» }\end{array}$ & Функції і керівництво ЛЦДН НПУ \\
\hline $\begin{array}{l}\text { «Положення про підготовку навчально- } \\
\text { методичних матеріалів для дистанційного } \\
\text { навчання» }\end{array}$ & $\begin{array}{l}\text { Механізм виготовлення, оплати і } \\
\text { відповідальність }\end{array}$ \\
\hline «Положення про використання дистанційних & Структура, функції і обов’язки всіх сторін \\
\hline
\end{tabular}


Науково-технічну документацію складали інструкції з розробки електронних засобів навчання й оволодіння навичками роботи 3 програмними продуктами як ліцензійними, так і тими, що вільно розповсюджуються. Для створення іï був використаний досвід, в основному, російських учених [5]. Хоча треба відзначити, що через деяку розбіжність у правових і законодавчих питаннях Росії й України, дещо доводилось генерувати, виходячи зі свого бачення.

Другий eman проекту (2008-2010) передбачав виконання низки першочергових практичних завдань у трьох напрямках, що створювало необхідні умови для закладання фундаменту основного - третього етапу проекту. До них належали:

1. Створення постійно діючої системи всеобучу всіх категорій працівників університету з питань оволодіння ІКТ-технологіями і системи їх стимулювання й заохочення.

2. Створення власного банку цифрових навчальних ресурсів (е-бібліотеки).

3. Створення систем доступу до освітніх ресурсів.

Перший напрямок: створення системи всеобучу з IKT. Загальновідомо, що існуючі Інтернет-освітні-ресурси, або ті, які можна знайти на $\mathrm{CD}$, не можуть повністю задовольнити потреби ВНЗ здійснювати навчальний процес за власними навчальними програмами чи авторськими курсами. На жаль, у педагогічному університеті не готують Веб-дизайнерів. Тому створення постійно діючої системи всеобучу навчально-допоміжного персоналу з питань виготовлення власних цифрових освітніх ресурсів стало першою необхідною умовою для забезпечення реалізації наступних етапів проекту. Для навчально-допоміжного персоналу кафедр підготовлено декілька програм короткочасних курсів із виготовлення різних електронних дидактичних матеріалів, наприклад: «Створення мультимедійного супроводу аудиторний лекцій 3 інтерактивними засобами навчання», «Виготовлення книг у форматі HTML», «Виготовлення книг у форматі DJVU» тощо. Через цю систему курсів пройшли більше 300 осіб - це представники всіх кафедр університету, про що свідчать отримані ними відповідні сертифікати про підвищення кваліфікації.

Як відомо, студенти - це майбутні викладачі і лаборанти кафедр університету, тому для забезпечення високого рівня їх підготовки з циклу дисциплін IКТ була 
відкрита загально-університетська кафедра інформаційно-комунікаційних технологій та електронних засобів навчання, яка забезпечує навчальний процес у більшості інститутів з дисциплін, пов’язаних з ІКТ: «Цифрові освітні ресурси» і «Інформаційнокомунікаційні технології у вищій школі». Розроблені нові навчальні плани i навчально-методичне забезпечення. Отримали гриф МОН України навчальний підручник для студентів ВНЗ «Інформаційно-комунікаційні технології навчання» А. П. Кудіна i навчальний посібник «Лабораторний практикум 3 інформаційнокомунікаційних технологій навчання» (під загальною редакцією А. П. Кудіна). Створено новий лабораторний цикл робіт (25 робіт).

Другий напрямок: створення банку цифрових навчальних ресурсів (ебібліотеки). Сучасна дидактична організація інформаційно-освітнього середовища навчального закладу зачіпає докорінну модернізацію джерел навчальної інформації. Наряду з друкованими паперовими виданнями стає необхідним використання видань на електронних носіях. Це зумовлено двома причинами.

Як відомо, у галузевих стандартах вищої освіти передбачено використання дисциплін і предметів на вибір. Зміст предметів на вибір зазнає постійних змін через швидкі зміни на ринку праці і бурхливий розвиток новітніх технологій. Зрозуміло, що централізоване забезпечення навчальною літературою 3 цих курсів, як правило, відсутнє. Тому зростає роль електронних навчальних посібників, які створені викладачами конкретного ВНЗ. Другою причиною, яка обумовлює зростаючий інтерес до електронних книг, є те, що електронні книги - це середовище, де дидактичні можливості можуть вноситись оперативно, на відміну від книжки на паперовому носії, де інформацію змінити неможливо (треба перевидавати книжку). Окрім цього, інформація може подаватися такими засобами, використання яких у паперових книгах неможливе (мультимедія, навігації, гіперпосилання і т. д.).

Для цього в університеті розроблено власне програмне забезпечення для виготовлення електронних книг. Виготовлено близько 3000 електронних книг - це навчальні підручники, посібники, навчальні матеріали до лекцій і семінарів. При службі порталу університету організований облік і експертиза виготовленої продукції. Разом із фінансовою частиною університету розроблена система оплати праці виготовлювачів ЦОРів, яка пов'язує розмір надбавки не тільки 3 кількістю виготовленої продукції, а і затребуваністю студентами виготовленої книги. Останнє 
здійснюється автоматично: на програмному рівні на порталі працює автоматизований облік «скачувань» кожної книги. Це стимулює викладачів кафедри виготовлювати тільки навчальну літературу в електронному форматі.

Третій напрямок: розробка систем доступу до цифрових навчальних ресурсів. Розробка систем доступу до цифрових навчальних ресурсів передбачала значні фінансові витрати на зміцнення матеріально-технічної бази проекту, що є на сьогодні основою будь-якого серйозного кроку в реалізації освітніх проектів. У цьому напрямку зроблено таке.

У повному обсязі введена в дію «Електронна бібліотека» на сервері університету, системи каталогізації електронних книг та їх захисту. Зроблена відкрита система доступу до ресурсів бібліотеки - через освітній портал університету: www.npu.edu.ua. В основі концепції освітнього порталу була покладена як технологія накопичення вікіпедія-технологія. Відповідно для реалізації таких підходів була розроблена «Концепція підготовки і функціональні обов’язки модераторів сайтів інститутів з числа лаборантів». Організовані курси підготовки модераторів сайтів усіх інститутів - спеціалістів із більш високим рівнем підготовленості з питань ІКТ. Через цю систему курсової підготовки пройшли 22 модераторів сайтів усіх інститутів. Для виготовлення сайтів інститутів обрано програмний продукт - Joomla 1,5.

Налагоджена локальна мережа університету, яка об’єднує всі навчальні корпуси і підрозділи університету на основі найновіших інформаційнокомунікаційних технологій (університетська мережа Інтернет - Інтранет) - близько 900 комп’ютерів. Придбано відповідне програмне забезпечення і введено в дію Центральний сервер університету, що має технічні параметри, які відповідають сучасних вимогам і дозволяють розміщувати і зберігати значні обсяги інформації. Відкрито 17 Центрів електронного навчання при інститутах, де студентам безкоштовно надається вільний доступ до навчальних електронних ресурсів бібліотек світу, у тому числі й «Електронної бібліотеки НПУ імені М. П. Драгоманова», i проводиться комп'ютерне тестування.

Tретій проекту (2010-2014 р.p.). Метою цього етапу є широкомасштабне впровадження інструментів і технологій електронного навчання у навчальний процес в університеті. На основі лінійки програмних продуктів Microsoft створено власну систему дистанційного навчання «Celsi», на якій розгорнуто апаратно-програмний 
комплекс «Електронний деканат», що здійснює автоматизовану дистанційну організацію навчального процесу через мережу Інтернет. Створено повноцінне навчально-методичне забезпечення навчального процесу за дистанційною технологією на двох спеціальностях бакалаврату «Біологія» $\mathrm{i}$ «очаткове навчання», $\mathrm{i}$ спеціальностями магістратури «Управління вищими навчальними закладами» i «Адміністративний менеджмент» (200 дистанційних курсів). Відкрито 3 локальні центри дистанційного навчання (м. Лубни Полтавської області, м. Добромиль Львівської області, м. Свпаторія АР Крим), через які вперше у 2010 році здійснено набір студентів на заочно-дистанційну форму навчання. Проведено сертифікацію підготовлених мережевих викладачів для проведення занять за дистанційною формою навчання. Створено студентське Інтернет-телебачення.

Важливою стороною роботи в цьому інноваційному напрямку сучасної педагогіки є визнання його результатів. Розробники концепції проекту отримали патент України [6], а також були запрошені як консультанти з питань впровадження IКТ в навчанні до деяких закордонних університетів (м. Шандон з Китаю, м. Шумен 3 Болгарії, м. Гродно з Білорусі, м. Волгоград (Росія) та ін.). Успішно пройшла презентація результатів на Міжнародних наукових форумах: майстер-клас на одному 3 найбільших європейських форумів з IT в освіті у м. Москва («ИТО-2008, 2010»), м. Варна (Болгарія), м. Прага (Чехія), на європейських виставках у м. Москва, м. Варшава («Perspectiwy» 2008, 2009) та ін.

На 2011-2012 роки запланова комплексна широкомасштабна інформатизація як організації, так і забезпечення навчального процесу в усіх інститутах університету, яка включає: впровадження електронної системи організації і контролю самостійної діяльності студентів у т. ч. стаціонару; організація дистанційної (e-learning) форми навчання для осіб, що навчаються без відриву від виробництва; використання в роботі деканатів систем АПК «Електронного деканату»; оволодіння всіма викладачами кафедр інститутів інноваційними технологіями викладання дисциплін на основі IКТ.

Для цього були розроблені проекти інформатизації до кожного інституту, які враховують їхню специфіку і потреби. Так для інституту фізичного виховання i спорту була розроблена нова дисципліна «Спортивно-педагогічна інформатика», для інституту політології та права «Правова інформатика» і т. і. Планується введення на педагогічних спеціальностях інститутів нової кваліфікації - мережевий викладач 
заочної форми навчання.

Висновки. Представлені результати і плани на найближчі роки свідчать про те, що головна мета проекту буде досягнута: НПУ імені М. П. Драгоманова стане «Електронним університетом». На нашу думку, серед ВНЗ саме педагогічні університети повинні бути «законодавцями моди» на інноваційні педагогічні технології, а не технічні університети, що спостерігається зараз.

\section{Список використаних джерел}

1. Солдаткин В. И. Создание информационно-образовательной среды открытого образования Российской Федерации // Новые информационные технологии в социально-гуманитарных науках и образовании: современное состояние, проблемы, перспективы развития / Под общ. ред. А. Н. Кулика. - М.: Логос. — 2003. - С. 161179.

2. Кудін А. П., Вакуленко I. В. Теоретичні засади підготовки викладача дистанційного навчання// Науковий часопис. НПУ імені М. П. Драгоманова, серія №5, Педагогічні науки: реалії та перспективи. - Випуск №18: Збірник наукових праць - К.: Вид. НПУ імені М. П. Драгоманова, 2009. - С. 125-131.

3. Андрущуенко В. П., Кудін А. П. Електронна педагогіка - впроваджуємо черговий новаторський проект // Всеукраїнський громадсько-політичний тижневик «Освіта». - 2009. - №46-47 (5377-5378). - С. 4-5.

4. Кудін А. П., Маркітан В. Впровадження Інтернет-орієнтованих систем електронного навчання у НПУ імені М. П. Драгоманова // Науковий часопис Національного педагогічного університету імені М. П. Драгоманова. Серія №5, Педагогічні науки: реалії та перспективи. - Випуск 21, Збірник наукових праць / За ред. Дмитренка П. В.. - К.: Вид. НПУ імені М. П. Драгоманова, 2010. - С. 100-109.

5. Инновационный подход к организации сетевого дистанционного обучения в вузе: принципы, состояние и первый опыт [Електронний ресурс] / С. Л. Лобачев. К вопросу создания системы сетевого ДО в ВУЗе: проблемы и пути решения // Телематика-2007: XIV Bcepocc. научн.-методич. конф. - СПб., 2007. Режим доступу до журн.: http://tm.ifmo.ru/tm2007/db/doc/get_thes.php?id=97. Заголовок з екрана.

6. Патент №33619 Україна, Н 04 В «Комплекс засобів для забезпечення інтерактивного навчального процесу» / Андрущенко В. П., Кудін А. П., Жабєєв Г. В., 
Падалка О. С.; заявник Національний педагогічний університет імені М. П. Драгоманова; заявл. 12.12.2007; опубл. 25.06.2008, Бюл. №23.

\section{ОБЩЕУНИВЕРСИТЕТСКИЙ ПРОЕКТ «ЭЛЕКТРОННАЯ ПЕДАГОГИКА»: ТРЕТИЙ ЭТАП}

Андрущенко Виктор Петрович, доктор философских наук, профессор, академик НАПН Украины, член-корреспондент НАН Украины, ректор Национального педагогического университета имени М. П. Драгоманова, г. Киев

Кудин Анатолий Петрович, доктор физико-математических наук, профессор, проректор по дистанционному образованию и инновационным технологиям обучения, Национальный педагогический университет имени М. П. Драгоманова, г. Киев

Падалка Олег Семенович, доктор педагогических наук, профессор, членкорреспондент НАПН Украины, проректор по организации учебно-воспитательной работы и экономики, Национальный педагогический университет имени М. П. Драгоманова, г. Киев

Вакуленко Ирина Викторовна, преподаватель кафедры информационнокоммуникационных технологий и электронных средств обучения Института дистанционного обучения, Национальный педагогический университет имени М. П. Драгоманова, г. Киев

Жабеев Георгий Владимирович, кандидат педагогических наук, доцент кафедры информационно-коммуникационных технологий и электронных средств обучения Института дистанционного обучения, Национальный педагогический университет имени М. П. Драгоманова, г. Киев

\section{Аннотация}

С целью создания современной информационно-образовательной среды НПУ имени М. П. Драгоманова была разработана концепция общеуниверситетского проекта «Электронная педагогика». Детально описаны этапы и задачи проекта. Приведены планы будущих этапов проекта.

Ключевые слова: проект, электронные средства обучения, информационнокоммуникационные технологии, интернет, сеть, мультимедиа, дистанционное обучение. 


\section{UNIVERSITY-WIDE PROJECT "E-PEDAGOGY": THIRD STAGE}

Andruchenko V., Doctor of philosophic sciences, professor, Academician of NAPS of Ukraine, Corresponding member of NAS of Ukraine, Rector of the National Pedagogical Dragomanov University, Kyiv

Kudin A., Doctor of physico-mathematical sciences, professor, Pro-rector on distance education and innovation learning technologies, National Pedagogical Dragomanov University, Kyiv

Padalka O., Doctor of pedagogical sciences, professor, Corresponding member of NAPS of Ukraine, Pro-rector on organization of educational work and economics, National Pedagogical Dragomanov University, Kyiv

Vakulenko I., lecturer of the Department of information and communication technologies and electronic learning tools, Institute of Distance Learning, National Pedagogical Dragomanov University, Kyiv

Zhabyeyev G., $\mathrm{PhD}$, associate professor of the Department of information and communication technologies and electronic learning tools, Institute of Distance Learning, National Pedagogical Dragomanov University, Kyiv

\section{Resume}

In order to create a modern information-educational environment of NPU named after Mykhailo Drahomanov the Concept of university-wide project "E-pedagogy" was developed. The stages and objectives of the project are described in details. Plans of future phases of the project are given.

Keywords: project, e-learning tutorials, information and communication technologies, Internet, network, multimedia, distance learning.

Матеріал надійшов до редакції 26.02.2011 p. 